Vol. 17, n² | 2013

Varia

\title{
Early Modern Violence and the Honour Code : From Social Integration to Social Distinction?
}

Gerd Schwerhoff

\section{OpenEdition}

\section{Journals}

\section{Electronic version}

URL: http://journals.openedition.org/chs/1426

DOI: $10.4000 /$ chs. 1426

ISSN: 1663-4837

\section{Publisher}

Librairie Droz

\section{Printed version}

Date of publication: 1 December 2013

Number of pages: $27-46$

ISBN: 978-2-600-01776-3

ISSN: $1422-0857$

\section{Electronic reference}

Gerd Schwerhoff, «Early Modern Violence and the Honour Code : From Social Integration to Social Distinction? », Crime, Histoire \& Sociétés / Crime, History \& Societies [Online], Vol. 17, n² | 2013, Online since 01 December 2016, connection on 21 April 2019. URL : http://journals.openedition.org/chs/1426 ; DOI : $10.4000 /$ chs. 1426 


\title{
Early Modern Violence and the Honour Code: From Social Integration to Social Distinction?*
}

\author{
Gerd Schwerhoff ${ }^{1}$
}

La question de l'honneur est d'une importance cruciale pour l'histoire de la violence, mais dans la plupart des cas on n'a qu'une compréhension assez limitée de son rôle. Cet article présente une typologie des différentes dimensions de l'honneur et avance l'hypothèse que le déclin de la violence aux XVII et XVIII siècles est lié à un changement de la principale fonction de celui-ci, soit le passage d'une fonction d'intégration sociale à une fonction de distinction sociale. Au cours du moyen-âge et des débuts de l'époque moderne, les conflits d'honneur violents pouvaient être lus comme l'indice d'une forte intégration sociale de l'ensemble des strates de la société et de la puissance des normes et des valeurs communes au noble comme au bourreau. Par la suite, la violence est devenue avant tout une manière d'affirmer ou d'imposer des distinctions sociales et de traiter les conflits au sein de groupes sociaux spécifiques, sans référence à une conception plus large et mieux partagée de l'honneur individuel.

Honour is of central importance within the context of a history of violence, but in most cases the understanding of the role of honour is fairly limited. The article develops a typology of different dimensions of honour and proposes the hypothesis that the decline of violence in the $17^{\text {th }}$ and $18^{\text {th }}$ centuries is linked to the change of the dominant function of honour, namely from social integration to social distinction. During the late Middle Ages and the beginning early modern era violent fights about honour could be deciphered as a strong indication of social integration crossing all social strata, for the power of common norms and values from the nobleman to the hangman. Afterwards violence became predominantly a means of asserting or imposing social distinctions and a way of dealing with conflicts within particular social groups without reference to a wider and shared understanding of individual honour.

* For fundamental corrections and improvements of the English version I am profoundly grateful to John Jordan, Oxford \& Dresden, and Richard Mc Mahon, Edinburgh.

1 Gerd Schwerhoff holds a chair for Early Modern History at the Technische Universität Dresden. Among his latest publications are (as an author) Historische Kriminalitätsforschung (2011) and (as editor) Stadt und Öffentlichkeit in der Frühen Neuzeit (2011); Das Duell. Ehrenkämpfe vom Mittelalter zur Moderne (together with U. Ludwig and B. Krug-Richter. 2012); Tribunal der Barbaren? Deutschland und die Inquisition in der Frühen Neuzeit (together with A. Burkardt, 2012); Göttlicher Zorn und menschliches Maß. Religiöse Abweichung in frühneuzeitlichen Stadtgemeinschaften (together with A. Kästner, 2013). 


\section{NUMBERS, INTERPRETATIONS AND THE HISTORIOGRAPHY ON VIOLENCE}

$\mathbf{R}$ esearch on violence has followed diverse and often difficult paths. We can, however, distinguish some main directions. On the one hand, there is a particular anthropological perspective which sees violence as a depressing constant in human societies with minimal historical variation. Wolfgang Sofsky, for instance, argues that the search for social meanings and causes of violence is in vain because violence is so often meaningless and pointless. Moreover, the search for meaning runs the danger of overlooking and neglecting the only and most important truth: the pain of the victims. ${ }^{2}$ On the other hand, there are those who emphasize historical variability but amongst these scholars there are also deep divisions. Within this group we can, following Max Weber, distinguish between 'Stoffhuber' and 'Sinnhuber': between the collectors of data and the collectors of meaning. ${ }^{3}$ The 'Stoffhuber' are the cliometricans who try to obtain a more thorough description and explanation of historical violence via quantification. The 'Sinnhuber', by contrast, rely on microhistories and, in doing so, follow the lead of Clifford Geertz by offering a 'thick description' of social and cultural life.

Naturally both approaches have their specific strengths and weaknesses. For those favouring a quantitative approach, violence remains a total black box. They can count homicides and violent incidents, they can develop theses about the ups and downs and they can speculate about the reasons for these conjunctures. Normally these reasons have an exogenous character, so they seldom focus on the violence itself. This approach is, however, quite limiting. As the German sociologist Trutz von Trotha argues (against the mainstream of his discipline), sociologists - following the classic route from Durkheim and Weber to Simmel and Elias - restrict their analysis to the reasons for violence instead of developing a real phenomenology of violence. ${ }^{4}$ Inspired by and drawing on such critiques, some cultural historians have searched for the meaning contained within violent actions rather than seeking to develop theories to explain apparent trends in violent activity over time. The strength of this approach, however, obviously lies in its synchronic perspective, not its diachronic analysis.

I concede that this description of the methodological and historiographical battlefield is too simplistic, although at the moment it is easy to find arguments in its favour. Take, for example, the new history of violence, written by Steven Pinker. His bold but highly problematic statements about the long term decline of violence from prehistoric times to the present are open to serious criticism. ${ }^{5}$ There is, however, also more sophisticated work which tries to integrate cultural aspects with a quantitative approach. One example is Pieter Spierenburg, a Dutch historian and follower of the sociologist Norbert Elias. Based on his own research about Amsterdam and also

Sofsky (1996, 1998); Lorenz (2004, p. 14).

Weber (1985, p. 214).

Trotha (1997).

Pinker (2011); see Ziemann (2012). Another example of an extreme quantitative approach is Eisner (2011) about "Patterns of Regicide" in Europe from 600 to 1800, who calculates "a homicide rate of about 1,000 per 100.000 ruler-years". For a more sophisticated approach to the history of violence based on numbers, see Roth (2009). 
the statistical series collected by others, particularly Manuel Eisner ${ }^{6}$, he argues for a "long-term decline of homicide" from the middle ages to the present. At the same time, however, he debates the "the crucial role of honor." Most forms of interpersonal violence in the past, he postulates, had something to do with the defence of male honour. As a logical consequence a convincing theory about honour must also include a temporal perspective. ${ }^{8}$ On the basis mainly of research about the history of literature he identifies "a shift from external to internal honor," something which is conceptualised in other contexts as a shift from 'honour' to 'dignity'. Spierenburg accentuates the change from a body-related sense of honour to a more spiritual one and calls this process the "spiritualization of honor." This bodily concept of honour was especially dominant within societies without a monopolization of state power and where male-dominated societies were based on an ethic of violent self-help. In this view, the process of civilization brought with it a shift towards a more spiritual sense of personal honour along with a decline in interpersonal violence. The main driving power behind this was "a decrease in male aggression."

Substantial contributions to the history of crime, whether preferring a qualitative or a quantitative point of view, have to integrate both perspectives. The emphasis on one side or the other will, of course, be different by 'Stoffhuber' or 'Sinnhuber'. Let me be very clear about my position from the start: I belong to the group of sceptics who do not believe in the validity of a long term decline in violence from the middle ages. ${ }^{10}$ In my view, all attempts to give a general interpretation based on trends in the incidence and nature of interpersonal violence are suggestive but misleading. The fragmented and very heterogeneous source materials and the often unreliable population figures mean such efforts are highly problematic and the willingness of many researchers to favour the highest figures as 'those closest to reality' is hard to take seriously. For centuries, from the middle ages up to the beginning of the early modern era it seems impossible to obtain the necessary weight and validity of data which might allow for the calculation of viable homicide rates. ${ }^{11}$ Relating the homicide rates to Elias' civilizing theory make things even worse. Elias argued that there were increasing levels of individual self-control over the course of the last seven centuries which were linked to the growth of the state's monopoly of power and the social division of labour. Without doubt, Elias' theory has its historical merits : linking individual psychic attitudes and emotions to social structures and tracing its historical change was a revolutionary undertaking in his day; and placing the concrete agents of this change in early modern court society was also path breaking. Today, however, in many ways his theory is outdated. On an empirical level, Elias' handling of the sources was very selective, his perception of the medieval period or French 'absolutism' was full of clichés and he ignored other hotspots of historical change such as religion or the city. On a more conceptual level, the theory of civilization is criticized because of its ideological character, its

\footnotetext{
6 Eisner (2001, 2004).

Spierenburg (2008, pp. 7-11).

Ibid., p. 9.

9 Ibid., p. 112. Shoemaker (2001) argues, with differences in detail, in the same direction on the basis of material from London.

10 See for the following Schwerhoff $(2002,2004)$.

11 Schwerhoff (2002, pp. 105ff.).
} 
teleological, evolutionist tendency and its simple, reductionist attitude. ${ }^{12}$ Violence, according to Elias, is simply there, a natural aptitude of human beings which has to be tamed socially step by step. Changes in the forms of violence, following this view, are always the dependent variable of anonymous processes of state formation or social differentiation. The steaming pot of human passions has to be capped by political and social repression. 13

It would be inequitable to push the theory of civilization completely aside but too often it is taken as the 'theoretical' counterpart to a seemingly obvious 'empirical' trend. So the theory is used to simply reinforce the 'long-term-decline-of-violence' trend. Unfortunately, the mainstream debate in the English-speaking world is dominated by this camp, represented by Spierenburg, Eisner, Pinker and others. Reading their publications it is irritating (and in some ways frustrating) that the objections raised in the work of other historians are not taken seriously. In most cases, these objections are just ignored or brushed aside with a short remark, hoping that a flood of empirical data will wash them away. ${ }^{14}$ This will not happen, and a serious discussion about the gritty empirical grounds of the data is badly needed. However, it is not the aim of this article to stress this point further.

My scepticism about the long term decline of violence does not indicate a total rejection of quantitative methods. On the contrary, a critical and careful reading of these numbers gives valuable hints to historical change in a more limited sense. Compared with other eras, the data on the early modern period is more thorough and reliable. On this basis it might be possible to postulate a decline of violence from the sixteenth to the eighteenth century. It is therefore worthwhile to take a second look at the reasons for this change and elaborate on some qualitative arguments. I concur with the thesis of Spierenburg (and others) that 'honour' is of crucial importance in this context but argue that it is possible to describe the role of honour differently. The change was not, as Spierenburg suggests, towards the 'spiritualization' of honour but rather there was a shift from a position where the dominant function of violence was integrative to one where violence became predominantly a means of asserting or imposing social distinctions and a way of dealing with conflicts within particular social groups without reference to a wider and shared understanding of individual honour. This article cannot, of course, offer a detailed account of this shift (that must await a more comprehensive work) but it will suggest some crucial indicators that a significant change occurred in the role of violence between the sixteenth and eighteenth centuries.

12 For a critique Schwerhoff (1998). For different approaches to the theory, see Watson (2007).

13 Trotha (1997), p. 14.

14 F.e. Eisner (2001, p. 74). The very short statement of Spierenburg (2002) cannot be classified as an appropriate answer to Schwerhoff (2002). This critique does not indicate that the English-speaking world belongs uniformly to the followers of the decline of violence-camp. See, for example, Carroll (2006) or McMahon (2007) for other views. See also the very cautious statement of the Doyen of English criminal historians about this problem (Sharpe, 1996) although it is published under the 'civilisation of crime'-flag. And even Roth, working in principle on the macro-historical level with quantitative approaches, belongs to the strong opponents of Elias (Roth, 2009). 


\section{DIMENSIONS OF HONOUR - A TYPOLOGY}

Honour is a very fluid substance: "What is honour?", asks Falstaff rhetorically in Sheakespeare's Henry IV (Act 5, Scene 1), and he gives the answer himself: "A word. What is in that word "honour"? [...] Air." Even modern historians describe it as the Loch Ness monster (often seen, but never caught) or as a chameleon. ${ }^{15}$ It is especially difficult to give a modern definition. Take for example the attempt by Wolfgang Weber in the Enzyklopädie der Neuzeit who defines honour as "a historical variable and complex control system of mutual allocation of values, which produced decisively individual self-respect as well as role - and groupspecific representations of social ranks and therefore appropriate expectations about the right behaviour." 16 This meandering definition offers some hints as to the complexity of the phenomenon.

Honour is bestowed by others ${ }^{17}$ but it is also related to self-respect. Many have postulated that over the course of previous centuries honour changed gradually from something bestowed by others to being a product largely of self-esteem. It is debatable, therefore, whether it would be better to call the modern concept of honour, 'dignity'. In this context it must be sufficient to define honour as a communicative code for the negotiation of a variety of issues. ${ }^{18}$

In the German historiography - and the present article is based mainly on German material - we can identify, over the last two decades, at least three main areas of research on honour. These areas refer to different spheres of early modern societies, and they reveal very different meanings and functions of honour and they are usually studied in isolation from each other. They are, however, linked in early modern society, and a comparative approach might be helpful in reaching a better understanding of the relationship between honour and violence.

Honour, violence and social integration: The first area of research centres on the part played by honour in acts of interpersonal violence, among men from similar social backgrounds. ${ }^{19}$ This includes studies of the role of injuries, the dynamics of violent rituals or the duel as a primary means of managing conflict. ${ }^{20} \mathrm{~A}$ common feature of this work is that the violent incidents are regularly related to the violation of the personal honour of a certain person through actions, gestures or words. Mostly

15 Dinges (1989, 1994); Speitkamp (2010, p. 319). For the research on honour in Germany, see Schreiner/ Schwerhoff (1995); Backmann et al. (1998); Kesper-Biermann et al. (2011); Ludwig et al. (2012).

16 Weber (2006). For a discussion of the classical concepts on honour (e.g. Max Weber, Pierre Bourdieu), see Schreiner, Schwerhoff (1995, p. 5).

17 Even in the middle of the eighteenth century, honour was defined in the most important encyclopedia of the German speaking Enlightenment as a result of attribution: „Ehre ist eine Meynung andrer Leute, nach der sie einem Menschen einen Vorzug vor den andern beylegen."(Johann Heinrich Zedler, Grosses vollständiges | UNIVERSAL | LEXICON | Aller Wissenschafften und Künste, 1734, vol. 8, Halle \& Leipzig, p. 223).

18 Schreinern Schwerhoff (1995, p. 9).

19 Spierenburg (2008, p. 9), following Frank Henderson Steward, addresses it as the 'vertical' dimension of honour in contrast to the 'horizontal' one.

20 For injuries, see most recently Haack (2009). The duel has been studied in Germany primarily for the nineteenth and twentieth centuries, and only recently became a subject of interest for those working on the early modern period. See Ludwig et al. (2012). 
these conflicts occurred between individuals or between members of small groups. In these contexts the semantics of honour follow a binary-coded logic: either one has honour or one has lost it. If he or she is not able or not willing to defend his or her honour, never mind how serious the risk, he or she runs the danger of total loss.

There was, of course, also a form of judicially-determined dishonour, the infamia juris, which functioned as a sort of model for the social loss of honour. It could lead to the dishonoured man or women being prevented from acting as an office holder or as a witness, and it could be enforced by 'Ehrenstrafen' like the pillory or branding. In the social world, however, the infamia facti, the bad reputation in public, had strong effects without formal legal sanction. ${ }^{21}$ A great fear of loss of honour can be observed across the social strata, in the world of the nobles and among craftsmen or peasants. Wolrad Müller, a forest warden in Canstein, in 1715 responded to a gesture in front of his wife, suspecting that it implied she was a whore, to insult his opponent Friedrich Ludey as a "Hundsfott" (caitiff) and to cuff him. ${ }^{22}$ Cases like this are at the centre of this article.

Honour, violence and social distinction: The second area of research has focused on the dishonourable and socially marginal. Here there is a particular focus on certain lowly occupations ${ }^{23}$ This field of the dishonourable, marked by contemporary jurists as levis macula nota, should not be jumbled with the honour/ dishonour paradigm. It concerns the attribution of inferior status to certain social groups, such as executioners, skinners, knackers, bailiffs, and some craftspeople, like linen weavers or barber-surgeons. In this social context, honour and dishonour could be graduated (the respectability of the bailiff was greater than that of the executioner) ${ }^{24}$ Conflicts over reputation were often settled on the margins of society between these poorlyrespected groups. A typical dispute arose when the son of an executioner wished to learn a trade regulated by a guild, which strongly opposed the entry of a member of the dishonourable to its world.

Of course, the status of the dishonourable could be used against them. But in principle, it was accepted by the whole society, that even the members of a disrespected group had their personal honour which had to be defended in case of conflict (at least if it had not been contaminated by criminal acts). Take, for example, the dispute over the medical activities of the executioner Lorenz Straßberger in the city of Görlitz in 1648. One day at the city gate it escalated into a violent confrontation with the barber Jacob Schwantiß. Schwantiß complained to the magistrates about Straßberger and demanded a severe punishment, but in return the executioner brought charges against the barber because of his injuries. According to his statement, the barber had denounced him as a 'Schelm' (a common term of abuse referring to a cadaver) and threatened him with murder and thus Straßberger's violence was a form of selfdefence. He insisted that many honourable people and craftsmen used his services and asked that Schwantiß be punished. He even turned the pike placing Schwantiß on

\footnotetext{
21 Nowosadtko (1993, pp. 362-363). See for shaming punishments Schwerhoff (1993); Lidman (2008).

22 Krug-Richter (2003, p. 272).

23 Executioners and knackers had a paradigmatic status in this respect, see Nowosadtko (1994); Stuart (2000).

24 Nowosadtko (1995).
} 
a par with the murderers and other criminals he punished. In the end the magistrate of Görlitz ruled in favour of the executioner against the barber. ${ }^{25}$

Executioners also became involved in violent confrontations with their social superiors. In 1592, a noble judge blamed the hangmen of Schongau, Johann Georg Abriel, for a failed execution. Abriel declared that he would like to settle the dispute with knives. ${ }^{26}$ In 1730, another executioner, Johann Michael Kober, chose a different option to deal with the judge who had arrested him. He sued him, claiming that the judge had treated him not "as an honest man but as a criminal". ${ }^{27}$

Honour, violence and the assertion of social superiority and political precedence: The third area of research focuses on estates-based status and the use of violence to assert precedence or superiority over another as a means of symbolic communication in politics and society. These conflicts occurred between noblemen or university members in the higher ranks of society, the princely courts or the Diet. While disrepute was a phenomenon at the margins of early modern society, the struggle for precedence took place among the upper strata. In the city of Leipzig in 1526, two bachelor students from the law faculty quarrelled with some masters of philosophy over who would claim precedence in the Corpus Christi procession. ${ }^{28}$ Estates-based status conflicts like these were par for the course in the early modern era, among university professors, citizens, noblemen or princes, among emissaries at the courts or among cities at the Diet in Regensburg. These conflicts emerged, as intensive new research has shown, not as the result of individual grievances or of archaic mentalities, but were very significant acts reflecting political struggles arising from the process of state building in the early modern period. ${ }^{29}$ From our perspective, however, it is significant, that in cases like the struggle in Leipzig 1526 (as in many comparable cases) there was no danger or possibility of a total loss of honour but rather a negotiation over different gradations of honour. Such disputes could, of course, be accompanied by injuries, and in extreme cases lethal violence.

I would like to stress the different functions of the honour code in these different areas and to propose a rough typology (see the scheme below) ${ }^{30}$ : the violent fights about honour are (a little bit paradoxical, I concede) a strong indication of social integration crossing all social strata, for the power of common norms and values from the nobleman to the hangman. ${ }^{31}$ In the other two areas, honour was a medium of social distinction or advancement. Social integration vs. social distinction - I will elaborate this opposition further in the course of the article.

\footnotetext{
Ratsarchiv Görlitz, Varia 97c. See for medical activities of hangmen Wilbertz (1999).

26 Nowosadtko (1994, p. 110).

27 Ibid., pp. 258, 260.

28 Weller (2006, pp. 267-270).

29 See Stollberg-Rilinger (2008).

30 Early reflections on this subject can be found in Schwerhoff (1993, pp. 182ff.).

31 See Schwerhoff (2004).
} 
Scheme: Dimensions of honour in the early modern period

\begin{tabular}{|l|l|l|l|}
\hline & I. honour/dishonour & $\begin{array}{l}\text { II. respectability/ } \\
\text { disrepute/ } \\
\text { dishonourability }\end{array}$ & $\begin{array}{l}\text { III. honour priority/ } \\
\text { precedence }\end{array}$ \\
\hline Actors & $\begin{array}{l}\text { Conflicts among } \\
\text { individuals. }\end{array}$ & $\begin{array}{l}\text { Conflicts among } \\
\text { individuals and groups. }\end{array}$ & $\begin{array}{l}\text { Conflicts among } \\
\text { individuals and groups. }\end{array}$ \\
\hline $\begin{array}{l}\text { Honour } \\
\text { code }\end{array}$ & binary encoded. & $\begin{array}{l}\text { binary or gradually } \\
\text { encoded. }\end{array}$ & gradually encoded. \\
\hline $\begin{array}{l}\text { Social } \\
\text { function }\end{array}$ & Social integration. & $\begin{array}{l}\text { Social distinction } \\
\text { among and from the } \\
\text { marginal groups. }\end{array}$ & $\begin{array}{l}\text { Social distinction } \\
\text { among the elite. }\end{array}$ \\
\hline
\end{tabular}

\section{THE PHENOMENOLOGY OF INTERPERSONAL VIOLENCE - A REMINDER}

For a discussion of the role of honour in violent conflicts it is useful to reflect on the phenomenology of interpersonal violence, as it is recorded in court records all over central Europe..$^{32}$ Despite some variations in detail it is possible to give an ideal type description of acts of interpersonal violence. If we exclude collective violence in protest, massacres, warfare, and domestic violence, the most important forms of violence in early modern Europe were ritualized struggles between men in public. Such struggles can be understood in the light of a process of escalation, which could start with verbal quarrels and could end - in extreme cases - with homicide. Between these two poles there were a variety of different stages, which followed a well-established set of social rules up to a certain point of no return. For this reason, some historians speak about the 'rituals', 'ceremonies' or 'liturgies' of violence.

No fixed script existed for the order of events in a conflict, but there was something like a set of 'behavioural components'. Most of the protagonists shared a common logic which shaped their actions or as Rainer Walz puts it - there was a form of reciprocal "agonal communication". Drawing on the sociologist Niklas Luhmann, Walz regards the "interaction among those present" and the focus on honour as being most characteristic of a rather simple social system such as that of the early modern rural society; but also the old urban society was - following Rudolf Schlögl - a form of "association among those present". Accordingly, the characteristic feature of this form of communication is the continuous screening of the acts and utterances of others and a clear willingness to react to any potentially defamatory act or utterance. No one involved wanted to lose face. ${ }^{33}$ In such circumstances, one might 'pay back' a person's accusations or threats with a similar act, gesture or insult or alternatively there might be an escalation of the conflict by responding with stronger words or even physical violence. $^{34}$

32 Schwerhoff (2004; pp. 226-229); Eibach (2009, pp. 195-198). Among the most important case studies for the German-speaking world are Schwerhoff (1991); Walz (1992); Schuster (2000); Lacour (2000); Wittke (2002); Eriksson/ Krug-Richter (2003); Eibach (2003); Behrisch (2005); Lorenz (2007).

33 Walz (1992, pp. 232-235); for urban society, see Schlögl (2004).

34 The contemporary jurisprudence conceded the insulted the right of ,retorsion', see Fuchs (1999 p. 56). 
A broad spectrum of insults, defamatory phrases and threats were an essential element of such reciprocal communication. Throughout northern Europe an almost canonical repertoire of insults prevailed: 'rogue' and 'thief' for men and 'whore' for women recur with an astonishing regularity. Despite all the standardization of phrases, insults and verbal injuries often emerged from and took on their specific meaning within particular contexts and might, as Barbara Krug-Richter has stressed, be creatively combined..$^{35}$ The line between mere calumnies and unspecified threats, on the one hand, and a very concrete threat of violence, on the other, was razor thin. To use the personal pronoun in the second person singular while addressing the other $(d u)$, or to snap one's fingers towards someone of higher rank, were meant to elevate one's own social status and/or to degrade the social position of one's opponent. One of the most important gestures of aggression was to challenge someone to come out of his house (Herausfordern aus dem Haus): If the attacker succeeded, his opponent would step out of a special place of peace, judicially protected as such; if the opponent did not appear, the attacker could revile him as a coward. ${ }^{36}$ In the latter case, the attacker might resort to a violent attack on the house, damaging its fence, smashing the windows or plunging a knife into the front door. As a substitute for the body of the other, the external frontiers of his possessions were damaged. When the opponents faced each other directly, specific threatening gestures marked the borderline between verbal and physical violence. When sharp tongues proved ineffective, the use of knives came into play. The 'drawing of knives' is a central threatening gesture in the dramaturgy of a conflict shortly before the use of physical violence. The first physical attack marks another stage of escalation. Knocking down the other's hat, for example, was the initial provocative and degrading act immediately prior to the use of fists. From that point, it was only a small step to a slap on the ear and thus to the use of direct physical violence.

\section{PROBLEMS OF INTERPRETATION}

This very short ideal-type profile of violence marks the starting point for a meaningful interpretation and attempt 'to make sense of violence'. Some serious objections are raised against this phenomenology in the historiography of the last decade. Eva Lacour, for instance, describes a large part of the violent deeds she found in her material as impulsive and affect-driven. ${ }^{37}$ In most cases, she claims, there was no staggered escalation. Fists and knives were applied fast and in an uncontrolled fashion. Violence, from this perspective, is simply irrational and compulsive, not a meaningful phenomenon. Certainly, certain phases and stages of violence evade a meaningful analysis. There are always some moments of meaningless violence. This is true especially when we concentrate on the moment of beating, thrusting or wounding alone. It is easy to see only 'naked' violence or pure aggression if we isolate the violent interaction from the context and the prehistory - a procedure which in my eyes is senseless for historians.

\footnotetext{
35 Krug-Richter (2003).

36 On the ritual of house-scorning, see Spierenburg (2008, p. 69).

37 Lacour (2000, pp. 174-177).
} 
In my view, a culturally and contextually sensible interpretation of violence also includes threatening gestures, words and acts. This may seem strange at first, viewed from the angle of a modern definition of violence, but not from the perspective of contemporaries. Although early modern jurisprudence was well able to differentiate between insults and beating to death, terms like iniuria realia, which could include extremely brutal acts of violence, marked a broadly overlapping zone between physical and 'verbal' violence.38 Undoubtedly, this was the judicial reflection of an existing social practice. In daily life, insulting words often marked the beginning of the spiral of violence. To talk about 'verbal violence' conforms to the view of contemporaries. Insults hurt their honour, which was at least as important as the integrity of their body. One could view this honour almost as being something like a 'second skin', which had to be defended against violent attacks just like one's physical skin. Injurious words always held the risk of leading to an escalation in violent activity. This escalation, however, rarely occurred because of the intervention of third parties. This is demonstrated in the striking evidence from late medieval Constance where in the court registers of judicial verdicts, violence is the most common type of delinquency but about 53 percent of these violent cases were cases of armed threats, namely knife drawing. ${ }^{39}$ Thus, over half of these conflicts stopped before open violence occurred. Late medieval Nuremberg reveals comparable data: people threatened with knives, but fought with fists. ${ }^{40}$

A second objection which I will touch on briefly is related to the importance of alcoholic drinks. Did alcoholic drinks generate violent behaviour? A typical excuse of the accused, that they were drunk when they committed violence, fits with an older form of cultural history which explains violence in the past as a sort of collective intoxication. ${ }^{41}$ Without delving into too much detail, I am inclined toward a position that alcoholic drinks promoted violence but did not cause it. ${ }^{42}$ In pre-modern Europe, alcohol was not only a staple food, but also a medium of sociability and therefore present in many forms of communication. The important role of alehouses and other spaces of commercial hospitality had the same roots : as a central stage of social life taverns were the scenes of conflicts and therefore also for violent acts..$^{43}$

'Conflicts' - this term is strongly connected with the analysis of violence. If violence was not purposeless and undirected, nor a rational instrument for the acquirement of material goods or for the extortion of sexual services, then it is, as Lars Behrisch has pointed out, best understood as a form of escalation of social conflicts. ${ }^{44}$ The phenomenology of violence in his area of research, the East German town of Görlitz, has, despite some peculiarities, revealed roughly the same pattern as in other towns of the era. The typical violent deed was the result of conflicts between neighbours and friends of the same social status, and occurred in the central places of the city, almost exclusively between men. ${ }^{45}$ But many researchers do not take full account of the complex link between violence and conflict. For instance,

\footnotetext{
Fuchs (1999, pp. 139-142).

Schuster (2000, pp. 71, 95).

Henselmeyer (2002, pp. 83-86).

Kaiser (2003); for a more sceptical view, see Martin (2009).

This question is discussed by Wettmann-Jungblut (2003).

Kümin (2005).

Behrisch (2005, pp. 109-112).

Ibid., pp. 116-118.
} 
take the commonly used perspective on violence as a form of 'conflict resolution'. Unless we consider the death of an adversary as a form of resolution, this approach is misleading. It is more reasonable to classify violence as a medium for conflict management, a medium which can be supplemented or surrogated by other mediums like negotiation, settlement or formal juridical processes. Certainly, conflicts could be often the reason for violence, but the reverse is also true: violence could be the reason for conflict. For example, if a verbal conflict escalated without a pre-existing dispute to a violent fight. Both possibilities were not mutually exclusive insofar as violent disputes could update and deepen older conflicts. The problem is that our sources, primarily court records, do not give us enough information to understand the whole complexity of most cases. The relationship between conflict, verbal disputes and physical violence could be highly complex and any ideal-type description of interpersonal violence has clear limits: some violence which seems to our eyes a spontaneous outcome may have been in reality the result of a hidden, but rational plan. If we concentrate on the play on the stage and try to understand the rules of the play, we cannot ignore our knowledge of the backstage events.

These considerations take us back to the problem of honour as a key term for the interpretation of reciprocal, violent communication in many German case studies. ${ }^{46}$ Does it really make sense to explain violence via honour? Are we somehow deluded if we think honour was everywhere in pre-modern society? Are we not fooled by those smart contemporaries who used the issue of honour as an excuse to hide their real, often very ordinary, materialistic motives? Eva Lacour has tried to solve the problem in the way that she classifies only those cases as honour conflicts where honour was the immediate reason or where the restitution of honour explicitly was intended. In her analysis honour conflicts are ranked on the same level as other types of violence, such as 'property fights,' 'revenge' and 'alehouse quarrels.' The author herself, however, admits that many other violent interactions, including those about property, could have a strong honour dynamic. Likewise, many types of conflict could be seen as vengeful aggression. ${ }^{47}$

Obviously it is unsatisfactory to conceptualize honour conflicts as one type of conflict among others (such as property quarrels) rather the meanings of conflict are on a different analytical level from honour. In contrast, historical-anthropological studies try to detect the intertwined relationships between conflicts about material interests and those about honour. People spoke about honour or made use of it in order to elevate their conflicts of interest to the level of conflicts about fundamental values. ${ }^{48}$ Historical anthropologists acknowledge this as a central function of the semantics of honour. Thus, no matter what the occasions or the reasons for most of the reciprocal violent quarrels were: the rigid honour code homogenized the heterogeneous motives by translating them into a common 'language'. In other words: no matter what a quarrel was 'actually all about' according to our modern understanding, conflicts fought out violently in the streets of early modern Europe according to the social logic of the actors were mostly about honour. The impending loss of honour constituted the motor of violence. In individual cases, the exact relationship between conflicts over material

\footnotetext{
46 See, for instance, my book on Cologne, which follows in the footsteps of Pierre Bourdieu, see Schwerhoff (1991, pp. 312-315).

47 Lacour (2000, pp. 120-122, 2001).

48 Dinges (1994, p. 414).
} 
interests and honour conflicts can hardly be assessed precisely. Often it is noticeable, however, that the original causes for the conflict paled in comparison to the quarrels that followed these initial incidents. ${ }^{49}$

This conception of honour is also the starting point for an approach that views violence as a medium of social control. This approach ${ }^{50}$ looks at first sight unusual because social control of violence normally entails the avoidance, ending or sanctioning of violent acts. Such an understanding is inevitable as long as we define violence as a loss of control. If we allow violent acts to be part of meaningful interaction our perspective changes. We need, of course, a broad understanding of social control. Following a suggestion by Martin Dinges for a suitable definition, social control would be any form of social interaction and communication in which persons or groups define deviant behaviour and react by taking measures against it. ${ }^{51}$ The criteria about what is deviant behaviour are variable. Within the honour code, the definition of deviant behaviour was different from that in the context of the formal laws. The language of honour always referred to commonly shared values and norms or aimed at suggesting a breach of norms by the opponent. In this special context, violence was not per se illegitimate but a justified act of self-help. It was a sort of defence or even a sanction against unwanted behaviour, a behaviour which was against the norms of everyday life.

\section{HONOUR, VIOLENCE AND SOCIAL CONTROL}

The semantics of honour took a central place in the conflict management of early modern societies. As a medium of social control, honour had a double quality: it caused conflicts, struggles and violence, but these conflicts show the high degree of social integration across the different social strata. One could say early modern society was united in violent conflicts. Violent communication was rooted at the heart of society in social and spatial dimensions. In the city of Cologne, for example, in the late sixteenth and in early seventeenth centuries, delinquency related to violence constituted the largest portion of all crimes..$^{52}$ Members of marginal groups were just as underrepresented as the rich and upper classes, the merchants and the savants - without doubt partly the result of legal selection processes. The brawlers were usually craftsmen, masters as well as journeyman, and urban day labourers and small office holders. Urban policemen (Gewaltdiener) and to a lesser extent students stood out as particularly violent groups. The topography of violence was spread out evenly over the whole city. Compared with modern cities, where we can observe a sharp contrast between the pacified centres and some violent peripheries like the 'banlieues' of Paris, the hotspots of violence in early modern Cologne were the focal points of communication and interaction: the market, the harbour and other central places in the city. In this picture fits the less astonishing fact that ale or wine houses and taverns often functioned as arenas for violent conflicts - around one

\footnotetext{
$49 \quad$ Walz (1992, p. 221).

50 Schwerhoff (2004); for similar arguments pertaining to modern criminality, see Black (1983).

51 Dinges (1994, pp. 169-172, 2004); for the social control paradigm in general see Bergalli, Sumner (1997).

52 Schwerhoff (1991, pp. 292-295).
} 
fifth of recorded acts of violence occurred in such places. There was also a certain concentration of violence in the evening hours and on Sundays - violence therefore was something like a leisure-time phenomenon.

The case of the city of Cologne may not be representative in all respects, but the observations about the social and spatial distribution of violence seem representative of a broader pattern. The early modern honour code followed (at least up to the beginning of the eighteenth century) a behavioural model that cut across class lines. Nobles, soldiers, students, artisans (masters, journeyman and apprentices alike) and vagrants all interacted and communicated in roughly the same manner, although many of them claimed special status and a higher type of honour. The elites, in particular, often cultivated a violent habitus. In late medieval Constance, the upper strata's participation in crimes of violence was above-average. The same is true for small-scale rural areas in the seventeenth and at the beginning of the eighteenth centuries. ${ }^{53}$

For many centuries conflicts of honour involving violence had little in common with a formal and 'civilized' duel following strict rules. In 1707, the Saxonian nobleman Carl Rudolf von Nostitz got into a struggle with his host Friedrich Wenzel von Gersdorff, and attacked him at the dinner table in front of his host's wife and children with his rapier, seriously wounding him in the head. Contemporaries had no problems in labelling this very spontaneous attack as a 'duel'. Conversely the fight of two furrier journeymen in Freiberg in Saxony in 1673 was also handled as a 'duel' and punished according to the appropriate royal mandate..$^{54}$

Of course, in these examples noble lords and artisans fought out their struggles among their own social class. Violence within social groups was far more common than violence that crossed social boundaries. This is true also for homicides in the city of Cologne: an analysis of the relationship between offenders and victims proves that both generally came from similar social milieus whether they knew each other before (as family members, neighbours or work-mates) or not. ${ }^{55}$ But in a stratified society like early modern Europe, violence was not the only intragroup phenomenon, as communication and interaction in general were intra-group phenomena.

This does not undermine the claim that honour has a socially integrative function. The reasons for this are two-fold. First the forms that violence took did not differ significantly between different social strata and, second, these violent conflicts could cross the social boundaries in principle. Of particular notoriety are the struggles between artisans and students in early modern university towns as an indicator of a common male youth culture ${ }^{56}$ and, as was documented above, even hangmen were prepared to respond with violence to the provocation of noble judges ${ }^{57} \mathrm{~A}$ manorial lord in the small Westphalian territories at the beginning of the eighteenth century did not stand so high above his subjects that they could not attack his honour. ${ }^{58}$

\footnotetext{
53 Schuster (2000, p. 362); Frank (1995, p. 337); Krug-Richter (2004, pp. 301-304).

54 Ludwig, Schwerhoff (2012, p. 29); Meier (2012, pp. 291-294).

55 Schwerhoff (1991), p. 310.

56 Krug-Richter (2004).

57 See above footnotes 23, 24 .

58 Krug-Richter (2004, p. 283).
} 
Overall there are many indications for an integrative function for honour (in the sense of the first dimension in our typology) in pre-modern societies. This function vaulted the 'more' or 'less' of state honour (in the sense of the third dimension of our typology) and even involved marginalized persons belonging to the dishonourable (the second dimension). It should not irritate us that the term 'social integration' is sometimes, in the debates of modern sociology, seen as intimately linked to nonviolence, or more specifically that the "non-violent intercourse of the members of a community among each other' is used as an indicator of social integration. ${ }^{59}$ To me, it seems more important that there existed specific shared expectations. The need to defend one's honour obviously was a central part of this expectation, and this is true across social groups from the nobleman to the hangman. So honour belonged to the most important factors for maintaining social order, notwithstanding the fact that it was in practice a source of violence and thus also of social disorder.

\section{FROM SOCIAL INTEGRATION TO SOCIAL DISTINCTION?}

During the early modern period, probably around 1700 (a more precise dating must be left to future research), things began to change and the common practices of honour conflict lost more and more of their power for social bonding. Once more I refer to the case of Cologne.$^{60}$ Compared to theft and moral delinquency, violent crimes (apart from homicides) declined dramatically; in particular, little brawls and fracases disappeared entirely from the criminal records. Only members of the lower and marginal classes remained as offenders in these records. It is possible that the offenders from the higher reaches of society disappeared only from the sources but not from the streets of Cologne. Other records suggest that the number of homicides around 1700 did not decline significantly ${ }^{61}$ but the indications of a changing profile of the homicide offenders are instructive: instead of the once ubiquitous knives, fire-arms became the dominant weapons - a clear indication that the 'professionals of violence', namely soldiers, were becoming the main protagonists. Although the streets of Cologne seemed no more secure than a hundred years earlier, the dramatis personae are different. What is visible here to some degree is the distinction and differentiation of social groups which previously had communicated intensely with each other, even in the medium of violence. It is obvious that the middle strata of society, especially the master craftsmen, withdrew from the public rituals of honour. Not only for Cologne but also for other cities this retreat of the elites and the middleclasses from the popular theatre of honour, including violent fights, can be observed. Many groups distanced themselves from violence-based honour conflicts. ${ }^{62}$

Many groups, however, did not withdraw from violence in principle. For instance, journeymen cultivated their violent habitus and transmitted it to the early proletariat and among the rural world in the Swiss alpine canton of Uri in the nineteenth

\footnotetext{
$59 \quad$ Fuchs (1999).

60 Schwerhoff $(2007,2008)$.

61 Schwerhoff (2008, pp. 78-80). Unfortunately the serial data for Cologne end in 1718. In London, for example, a sharp decline of homicides can be observed for the period after 1720, see Shoemaker (2001, p. 193).

62 Eibach (2009, p. 201).
} 
century male honour remained the dynamic factor in many types of public, violent conflicts. ${ }^{63}$ Defending one's honour, through violent means also remained a medium for social integration among the nobles, the military and the students. ${ }^{64}$ What was disappearing in cities like Cologne in the eighteenth century was a common culture of violence that crossed and united the different social groupings in the cities. Instead several subcultures of violence emerged, part of the general trend of cultural disynchronisation of the social classes which began, according to Robert Muchembled, in the Renaissance. ${ }^{65}$ The proliferation of firearms could be a symbol of this disynchronisation: their possession was less trivial than that of bread knives in earlier centuries, it was linked more to professional groups like soldiers.

The quantitative decline of violence in the seventeenth and eighteenth centuries (if it occurred at all), then, seems to have a close correlation to the changing forms of violence in the early modern era. What are the specific reasons for these developments, if we do not feel satisfied with the passe-partout explanation offered by the civilization theory? One element of explanation of course might be the suppression of violence through the medium of criminal law. Another element could be the promise of conflict regulation offered by the state courts. But we need additional explanations. One very attractive one was generated by Joachim Eibach: he sees the process of the adoption of bourgeois standards of behaviour (Verbürgerlichung) as the development of a new mainstream culture with a new, more peaceful form of sociability. The peaceful coffee house replaced the rambunctious tavern, the middleclasses disassociated itself from the old culture and adopted the new ideal of civility. Violence remained only at the bottom or margins of society. ${ }^{66}$ It is easy to integrate "the spiritualization of honor," postulated by Pieter Spierenburg, in this model. Honour as personal reputation and virtue fits well into the patterns of civil society and culture.

But that picture needs an addition, if not a correction. There was a form of violent conflict management that not only remained but was fostered and nursed through the eighteenth and nineteenth centuries: the duel. This highly ritualized form of fighting remained popular among the nobility, the military, students and many citizens. This late boom of the duel in Germany is noteworthy. ${ }^{67}$ It indicates that the social elites did not wholly refute violent conflict management in principle; rather they cultivated violence in the form of a ritual that combined virile courage with the demonstration of a distinct social status. The need to give satisfaction (Satisfaktionsfähigkeit) was born. The classical codification of this capability was made in 1794 in the 'Allgemeines Landrecht für Preußische Staaten' which distinguished the duel as a privileged form of fight between nobles and military officers from other ordinary forms of violent aggressions which were regarded as attempted murder. ${ }^{68}$

\footnotetext{
63 Jessen (1992) ; Töngi (2004, p. 390).

64 See the reflections about 'competition games' as a genre of honour conflicts among early modern military officers by Ludwig (2011).

65 Muchembled (1988).

66 Most recently Eibach (2009, pp. 202-203).

67 See Ludwig et al. (2012), in contrast to the decline of dueling in England (Shoemaker, 2001).

68 Frevert (1991, p. 76).
} 
According to Pieter Spierenburg, the strict codification and the temporal and spatial separation between conflict and the duel can be regarded as a form of civilization. In my view, the most characteristic element of the late duels is their socially distinctive force. That violence could be channelled into a socially distinctive ritual is a strong symbol for the disintegration of the old culture of violence. We should not, therefore, understand the distinctive quality of honour as a completely new phenomenon - as we have seen this dimension was present during the whole early modern period, especially in the context of conflicts over social rank and precedence (the third dimension of our scheme). There was a sometimes open, sometimes hidden tension to the dimension of personal honour respective to the danger of a total loss of honour. Now, at the end of the period, this distinctive dimension of honour gained the upper hand, paradoxically just in that historical moment when the estate-based society came under heavy critique from Enlightenment thought.

The socially integrative dimensions of honour, present during earlier centuries, now only claimed relevance within each social peer group. Its function as a control mechanism for the society as a whole was over. Honour in the sense of the first dimension of our scheme belongs to the 'world we have lost' - no reason for sorrow considering its great potential for conflict and violence but it has to be acknowledged that the change in violence is not or not alone caused by a process of civilization, of internalization and spiritualization of honour which matches with the success story of modernity. The change in patterns of violence was connected with a growing and open social distinction and was by no means rooted in a rejection of violence. From then on interpersonal violence referring to honour concepts was only to be practiced among social equals. That this is not true for all or even the most forms of violence should be clear. But that is another story.

Prof. Gerd Schwerhoff

TU Dresden, Institut für Geschichte 01062 Dresden - D gerd.schwerhoff@tu-dresden.de

\section{REFERENCES}

Backmann, S. et al. (Eds), Ehrkonzepte in der Frühen Neuzeit: Identitäten und Abgrenzungen, Berlin, Akademie Verlag, 1998.

Behrisch, L., Städtische Obrigkeit und soziale Kontrolle. Görlitz 1450-1600, Epfendorf, bibliotheca academica, 2005.

Bergalli, R., Sumner, C. (Eds), Social Control and Political Order. European Perspectives at the End of the Century, London, SAGE, 1997.

Black, D., Crime as social control, American Sociological Review, 1983, 48, pp. 34-45.

Carroll, S., Blood and Violence in Early Modern France, Oxford, Oxford University Press, 2006.

Dinges, M., Die Ehre als Thema der Stadtgeschichte. Eine Semantik am Übergang vom Ancien Régime zur Moderne, Zeitschrift für Historische Forschung, 1989, 16, pp. 409-440.

Dinges, M., Der Maurermeister und der Finanzrichter. Ehre, Geld und soziale Kontrolle im Paris des 18. Jahrhunderts, Göttingen, V\&R, 1994. 
Dinges, M., The Uses of Justice as Form of Social Control in Early Modern Europe, in Roodenburg, H., Spierenburg, P. (Eds), Social Control in Europe 1500-1800, Columbus, Ohio State University Press, 2004, pp. 159-175.

Eibach, J., Frankfurter Verhöre. Städtische Lebenswelten und Kriminalität im 18. Jahrhundert, Paderborn, Schoeningh, 2003.

Eibach, J.,Gibt es seine Geschichte der Gewalt? Zur Praxis des Konflikts heute, in der Vormoderne und im 19. Jahrhundert, in Habermas, R., Schwerhoff, G. (Eds), Verbrechen im Blick. Perspektiven einer neuzeitlichen Kriminalitätsgeschichte, Frankfurt, Campus, 2009, pp. 182-216.

Eisner, M. Individuelle Gewalt und Modernisierung in Europa, 1200-2000, in Albrecht, G., Backes, O. (Eds), Mythos Gewalt, Frankfurt, Suhrkamp, 2001, pp. 71-100.

Eisner, M., The Long-term Development of Violence: Empirical Findings and a Theoretical Approach to Interpretation, in Hagan, J., Heitmeyer, W. (Eds), International Handbook of Violence Research, New York, Westview Press, 2004, pp. 41-66.

Eisner, M., Killing Kings. Patterns of Regicide in Europe, AD 600-1800, British Journal of Criminology, 2011, 51, pp. 556-577.

Eriksson, M., Krug-Richter, B. (Eds), Streitkulturen. Gewalt, Konflikt und Kommunikation in der ländlichen Gesellschaft (16.-19. Jahrhundert), Köln, Böhlau, 2003.

Frank, M., Ehre und Gewalt im Dorf der Frühen Neuzeit. Das Beispiel Heiden (Grafschaft Lippe) im 17. und 18. Jahrhundert, in Schreiner, K., Schwerhoff, G. (Eds), Verletzte Ehre. Ehrkonflikte in Gesellschaften des Mittelalters und der Frühen Neuzeit, Köln, Böhlau, 1995, pp. 320-338.

Frevert, U., Ehrenmänner. Das Duell in der bürgerlichen Gesellschaft, München, C.H Beck, 1991.

Fuchs, D., Soziale Integration und politische Institutionen in modernen Gesellschaften. Discussion Paper FS-III 99-203, Berlin, Wissenschaftszentrum, 1999. URL [http:// bibliothek.wz-berlin.de/pdf/1999/iii99-203.pdf].

Fuchs, R.-P., Um die Ehre. Westfälische Beleidigungsprozesse vor dem Reichskammergericht 1525-1805, Paderborn, Schoeningh, 1999.

Haack, J., Der vergällte Alltag. Zur Streitkultur im 18. Jahrhundert, Köln, Böhlau, 2009.

Henselmeyer, U., Ratsherren und andere Delinquenten. Die Rechtsprechungspraxis bei geringfügigen Delikten im spätmittelalterlichen Nürnberg, Konstanz, UVK, 2002.

Jessen, R., Gewaltkriminalität im Ruhrgebiet zwischen bürgerlicher Panik und proletarischer Subkultur, in Kift, D. (ed.), Kirmes - Kneipe - Kino. Arbeiterkultur im Ruhrgebiet zwischen Kommerz und Kontrolle (1850-1914), Paderborn, Schöningh, 1992, pp. 226-255.

Kaiser, R., Trunkenheit und Gewalt im Mittelalter, Köln, Böhlau, 2003.

Kesper-Biermann, S. et al. (ed.), Ehre und Recht. Ehrkonzepte, Ehrverletzungen und Ehrverteidigungen vom späten Mittelalter bis zur Moderne, Leipzig, Meine, 2011.

Krug-Richter, B., Von nackten Hummeln und Schandpflastern. Formen und Kontexte von Rauf - und Ehrhändeln in der westfälischen Gerichtsherrschaft Canstein um 1700, in Eriksson, M., Krug-Richter, B. (Eds), Streitkulturen. Gewalt, Konflikt und Kommunikation in der ländlichen Gesellschaft (16.-19. Jahrhundert), Köln, Böhlau, 2003, pp. 269-307.

Krug-Richter, B., Du Bacchant, quid est grammatica? Konflikte zwischen Studenten und Bürgern im frühneuzeitlichen Freiburg/Br., in Krug-Richter, B., Mohrmann, R.-E. (Eds), Praktiken des Konfliktaustrags in der Frühen Neuzeit, Münster, Rhema, 2004, pp. 79-104.

Kümin, B., Friede, Gewalt und öffentliche Räume - Grenzziehungen im alteuropäischen Wirtshaus, in Ulbrich, C. et al. (Eds), Gewalt in der Frühen Neuzeit. Beiträge zur 5. Tagung der Arbeitsgemeinschaft Frühe Neuzeit im VHD, Berlin, Dunker \& Humblot, 2005, pp. 131-143. 
Lacour, E., Schlägereyen und Unglücksfälle. Zur Historischen Psychologie und Typologie von Gewalt in der frühneuzeitlichen Eifel, Egelsbach, Dr. Hänsel-Hohenhausen, 2000.

Lacour, E., Faces of Violence Revisited. A Typology of Violence in Early Modern Rural Germany, Journal of Social History, 2001, 35, pp. 649-668.

Lidman, S., Zum Spektakel und Abscheu. Schand - und Ehrenstrafen als Mittel öffentlicher Disziplinierung um 1600, Frankfurt, Peter Lang, 2008.

Lorenz, M., Physische Gewalt - ewig gleich? Die Problematik absoluter Theorien im Spiegel historischer Kontexte und veränderter Körperwahrnehmung', Wiener Zeitschrift zur Geschichte der Neuzeit, 2004, 8, pp. 9-24.

Lorenz, M., Das Rad der Gewalt. Militär und Zivilbevölkerung in Norddeutschland nach dem Dreißigjährigen Krieg (1650-1700), Köln, Böhlau, 2007.

Ludwig, U., Von Scherzen und Duellen. Wettkampfspiele als Typus von Ehrkonflikten im schwedisch-pommerschen Offizierskorps, Zeitschrift für Historische Forschung, 2011, 38, pp. 371-403.

Ludwig, U. et al. (Eds), Das Duell. Ehrenkämpfe vom Mittelalter bis zur Moderne, Konstanz, UVK, 2012.

Ludwig, U., Schwerhoff, G., Ansichten zum Duell. Geschichtswissenschaftliche Zugänge, in Ludwig, U. et al. (Eds), Das Duell. Ehrenkämpfe vom Mittelalter bis zur Moderne, Konstanz, UVK, 2012, pp. 29-38.

Martin, A. L., Alcohol, Violence, and Disorder in Traditional Europe, Kirksville (Missouri), Truman State University Press, 2009.

McMahon, R., "Do you want to pick a fight out of me, or what do you want ?" Homicide and Personal Animosity in Pre-Famine and Famine Ireland, in Watson, K.D. (ed.), Assaulting the past. Violence and Civilization in Historical Context, Newcastle, Cambridge Scholars Publishing, 2007, pp. 222-249.

Meier, A., Handwerkerduelle im frühneuzeitlichen Kursachsen als (außer-) gewöhnliche Gewaltrituale, in Ludwig, U. et al. (Eds), Das Duell. Ehrenkämpfe vom Mittelalter bis zur Moderne, Konstanz, UVK, 2012, pp. 289-299.

Muchembled, R., L'invention de l'homme moderne. Sensibilités, mours et comportements collectifs sous l'Ancien Régime, Paris, Fayard, 1988.

Nowosadtko, J., Die Ehre, die Unehre und das Staatsinteresse. Konzepte und Funktionen von ,Unehrlichkeit' im historischen Wandel am Beispiel des Kurfürstentums Bayern, Geschichte in Wissenschaft und Unterricht, 1993, 44, pp. 362-381.

Nowosadtko, J., Scharfrichter und Abdecker. Der Alltag zweier, unehrlicher Berufe' in der Frühen Neuzeit, Paderborn, Schoeningh, 1994.

Nowosadtko, J., Umstrittene Standesgrenzen: Ehre und Unehrlichkeit der bayerischen Schergen, in Schreiner, K., Schwerhoff, G. (Eds), Verletzte Ehre. Ehrkonflikte in Gesellschaften des Mittelalters und der Frühen Neuzeit, Köln, Böhlau, 1995, pp. 166-182.

Pinker, S., The Better Angels of our Nature. The Decline of Violence in History and its Causes, New York, Viking, 2011.

Roodenburg, H., Spierenburg, P. (Eds), Social Control in Europe (1500-1800), Vol. 1, Columbus, Ohio State University Press, 2004.

Roth, R., American Homicide Supplemental Volume (AHSV). Civilization Thesis (CT). A supplement to Randolph Roth, 'American Homicide', The Belknap Press of Havard University Press, 2009 (online [http://cjrc.osu.edu/researchprojects/hvd/AHSV/tables/ AHSV\%20Civilization\%20Thesis.pdf]).

Schlögl, R., Vergesellschaftung unter Anwesenden. Zur kommunikativen Form des Politischen in der vormodernen Stadt, in Schlögl, R. (ed.), Interaktion und Herrschaft. Die Politik der frühneuzeitlichen Stadt, Konstanz, UVK, 2004, pp. 9-60. 
Schreiner, K., Schwerhoff, G. (Eds), Verletzte Ehre. Ehrkonflikte in Gesellschaften des Mittelalters und der Frühen Neuzeit, Köln, Böhlau, 1995.

Schuster, P., Eine Stadt vor Gericht. Recht und Alltag im spätmittelalterlichen Konstanz, Paderborn, Schoeningh, 2000.

Schwerhoff, G., Köln im Kreuzverhör. Kriminalität, Herrschaft und Gesellschaft in einer frühneuzeitlichen Stadt, Bonn, Bouvier, 1991.

Schwerhoff, G., Verordnete Schande? Spätmittelalterliche und frühneuzeitliche Ehrenstrafen zwischen Rechtsakt und sozialer Sanktion, in Blauert, A., Schwerhoff, G. (Eds), Mit den Waffen der Justiz. Zur Kriminalitätsgeschichte des Spätmittelalters und der Frühen Neuzeit, Frankfurt, Fischer, 1993, pp. 158-188 \& 236-240.

Schwerhoff, G., Zivilisationsprozeß und Geschichtswissenschaft. Norbert Elias' Forschungsparadigma in historischer Sicht, Historische Zeitschrift, 1998, 266, pp. 561-605.

Schwerhoff, G., Criminalized violence and the civilizing process - a reappraisal, Crime, History \& Societies, 2002, 6, 2, pp. 103-126.

Schwerhoff, G., Social Control of Violence, Violence As Social Control: The Case of Early Modern Germany, in Roodenburg, H., Spierenburg, P. (Eds), Social Control in Europe (1500-1800), Vol. 1, Columbus, Ohio State University Press, 2004, pp. 220-246.

Schwerhoff, G., Justice et honneur. Interpréter la violence à Cologne (XVe-XVIII ${ }^{\mathrm{e}}$ siècles), Annales. Histoire, Sciences sociales, 2007, 62, pp. 1031-1061.

Schwerhoff, G., Kriminalität in der Reichsstadt Köln um 1700 - ein neuer Blick vom Turm, Geschichte in Köln, 2008, 55, pp. 63-85.

Sharpe, J.A., Crime in England: Long-Term Trends and the Problem of Modernisation, in Johnson, E.A., Monkkonen, E.H. (Eds), The Civilization of Crime. Violence in Town and Country since the Middle Ages, Urbana and Chicago, University of Illinois Press, 1996, pp. 17-34.

Shoemaker, R,. Male honour and the decline of public violence in eighteenth-century London, Social History, 2001, 26, pp. 190-208.

Sofsky, W., Traktat über die Gewalt, Frankfurt, S. Fischer, 1996 (in French: Traité de la violence, Paris, Gallimard, 1998).

Speitkamp, W., Ohrfeige, Duell und Ehrenmord. Eine Geschichte der Ehre, Stuttgart, Reclam, 2010.

Spierenburg, P., Theorizing in Jurassic Park: A reply to Gerd Schwerhoff, Crime, History \& Societies, 2002, 6, 2, pp. 127-128.

Spierenburg, P., A History of Murder. Personal Violence in Europe from the Middle Ages to the Present, Cambridge, Polity Press, 2008.

Stollberg-Rilinger, B., La communication symbolique à l'époque pré-moderne. Concepts, thèses, perspectives de recherche, Trivium, 2008, 2. URL [http ://trivium. revues.org/1152].

Stuart, K., Defiled Trades and Social Outcasts: Honor and Ritual Pollution in Early Modern Germany, Cambridge, Cambridge University Press, 2000.

Trotha, T. von, Zur Soziologie der Gewalt, in Trotha, T. von (ed.), Soziologie der Gewalt, Opladen, Westdeutscher Verlag, 1997, pp. 9-56.

Töngi, C., Um Leib und Leben. Gewalt, Konflikt Geschlecht im Uri des 19. Jahrhunderts, Zürich, Chronos, 2004.

Walz, R., Agonale Kommunikation im Dorf der Frühen Neuzeit, Westfälische Forschungen, 1992, 42, pp. 215-251.

Watson, K. D. (ed.), Assaulting the Past. Violence and Civilisation in Historical Context, Newcastle, Cambridge Scholars Publishing, 2007.

Weber, M., Die „Objektivität“sozialwissenschaftlicher und sozialpolitischer Erkenntnis [1902], in Weber, M., Gesammelte Aufsätze zur Wissenschaftslehre, Tübingen, J. C. B. Mohr (Paul Siebeck), 1985, pp. 146-214. 
Weber, W. E., Ehre, in Enzyklopädie der Neuzeit, 2006, 3, pp. 77-83.

Weller, T., Theatrum Praecedentiae. Zeremonieller Rang und gesellschaftliche Ordnung in der frühneuzeitlichen Stadt: Leipzig 1500-1800, Darmstadt, WBG, 2006.

Wettmann-Jungblut, P., Gewalt und Gegen-Gewalt. Gewalthandeln, Alkoholkonsum und die Dynamik von Konflikten anhand eines Fallbeispiels aus dem frühneuzeitlichen Schwarzwald, in Eriksson, M., Krug-Richter, B. (Eds), Streitkulturen. Gewalt, Konflikt und Kommunikation in der ländlichen Gesellschaft (16.-19. Jahrhundert), Köln, Böhlau, 2003, pp. 17-58.

Wilbertz, G., Scharfrichter, Medizin und Strafvollzug in der Frühen Neuzeit, Zeitschrift für Historische Forschung, 1999, 26, pp. 515-555.

Wittke, M., Mord und Totschlag? Gewaltdelikte im Fürstbistum Münster 1580-1620. Täter, Opfer und Justiz, Münster, Aschendorff, 2002.

Ziemann, B., Eine "neue Geschichte der Menschheit"? Anmerkungen zu Steven Pinkers evolutiver Deutung der Gewalt, Mittelweg, 2012, 36, 3, pp. 45-56. 